\title{
Transethmoidal Encephalocele After Reduction of High Intracranial Pressure in Aqueductal Stenosis
}

\author{
Akuadukt Stenozunda Yïksek Intrakraniyal Basincin Azaltrlmast \\ Sonrasinda Transetmoidal Ensefalosel
}

\author{
Guive SHARIFI ${ }^{1}$, Ehsan ALAVI ${ }^{1}$, Maryam JALESSI ${ }^{2}$, Karim HADDADIAN ${ }^{1}$, Faezeh FARAMARZI ${ }^{1}$ \\ ${ }^{1}$ Loghman Hakim Hospital, Shabid Beheshti University of Medical Sciences, Tehran, Iran \\ ${ }^{2}$ Head and Neck Surgery Center, Rasool Akram Hospital, Tebran, Iran
}

Corresponding Author: Ehsan ALAVI / E-mail: ehsanalavi1978@yahoo.com

\begin{abstract}
Acquired non-traumatic transethmoidal encephaloceles are very infrequent lesions that are generally caused by a tumor or hydrocephalus. As far as we know, there is no reported case of encephalocele after CSF diversion in the literature.

We present a 25 -year-old woman with hydrocephalus due to aquiductal stenosis who was treated with endoscopic third ventriculostomy. Nine months later, she had developed rhinorrhea and on imaging she had a transethmoidal encephalocele. She underwent endonasal endoscopic repair of the defect and removal of herniated parenchyma.

CSF diversion to parasellar cisterns is not a known iatrogenic cause of basal encephalocele and is not noted elsewhere as a complication of third ventriculostomy. However, as third ventriculostomy is performed usually for intracranial hypertension treatment and intracranial hypertension itself is a known but rare cause of lacunar skull defect and encephalocele, this co-incidence may occur.
\end{abstract}

KEYWORDS: Encephalocele, Rhinorrhea, Hydrocephalus, Stenosis

öz

Akkiz non-travmatik transetmoidal ensefaloseller genel olarak bir tümör veya hidrosefali nedeniyle gelişen çok nadir lezyonlardır. Bildiğimiz kadarıyla literatürde BOS diversiyonu sonrasında bildirilen ensefalosel olgusu yoktur.

Akuedukt stenozu nedeniyle hidrosefalisi olan ve endoskopik üçüncü ventrikülostomi ile tedavi edilmiş 25 yaşında bir kadını bildiriyoruz. Dokuz ay önce rinore gelişmiş ve görüntülemede transetmoidal ensefalosel bulunmuştu. Endonazal endoskopik yolla defekt tamir edilip herniye parankim çıkarıldı.

Parasellar sisternlere BOS diversiyonu bazal ensefaloselin bilinen bir iatrojenik nedeni değildir ve üçüncü ventrikülostominin bir komplikasyonu olarak başka yerde bahsedilmemiştir. Ancak üçüncü ventrikülostomi genellikle intrakraniyal hipertansiyon tedavisi için yapıldığından ve intrakraniyal hipertansiyonun kendisi laküner kafatası defekti ve ensefaloselin bilinen ama nadir bir nedeni olduğundan birlikte görülme mümkündür.

ANAHTAR SÖZCÜKLER: Ensefalosel, Rinore, Hidrosefali, Stenoz

\section{INTRODUCTION}

Acquired cerebrospinal fluid leaks and cephaloceles can be divided into posttraumatic, iatrogenic, and spontaneous. The latter two categories can be particularly challenging to explain due to their mechanisms, and congenital or acquired thinning of the skull base. Some authors hypothesize that patients with increased CSF pressure are at increased risk of developing CSF leak and encephalocele.

\section{CASE CLINICAL DETAILS}

A 25-year-old woman was admitted to our hospital with a complaint of headache for two years without decreased visual acuity. Magnetic resonance imaging revealed dilation of lateral and third ventricles and aqueductal stenosis
(Figure $1 \mathrm{~A}, \mathrm{~B})$. The patient underwent endoscopic third ventriculostomy for the treatment of hydrocephalus. The CSF opening pressure was quite high during surgery.

She was asymptomatic when she was subsequently discharged from the hospital. Nine months later, this patient was readmitted to the hospital with history of intermittent rhinorrhea of one-month duration. Computed tomography showed a good response to third ventriculostomy (Figure $2 A, B)$ but brain MRI revealed dural sac and medial orbitofrontal gyrus herniation in right ethmoid sinus (Figure $3 \mathrm{~A}, \mathrm{~B}$ ). The size of the bone defect was $5 \mathrm{~mm} \times 5 \mathrm{~mm}$ and it was located on fovea ethmoidalis. She had a large meningoencephalocele of $1.5 \mathrm{~cm}$. She underwent repair of the defect by endoscopic endonasal approach and duraplasty and the brain sag 
was resected. She was discharged home on the fifth postoperative day. She exhibited no rhinorrhea at the 1- and 6-month follow-up reviews.

\section{DISCUSSION}

Acquired encephaloceles have a traumatic origin in $96 \%$ of patients. The next most common causes are tumors and hydrocephalus, which account for $3 \%$ to $5 \%$ of acquired
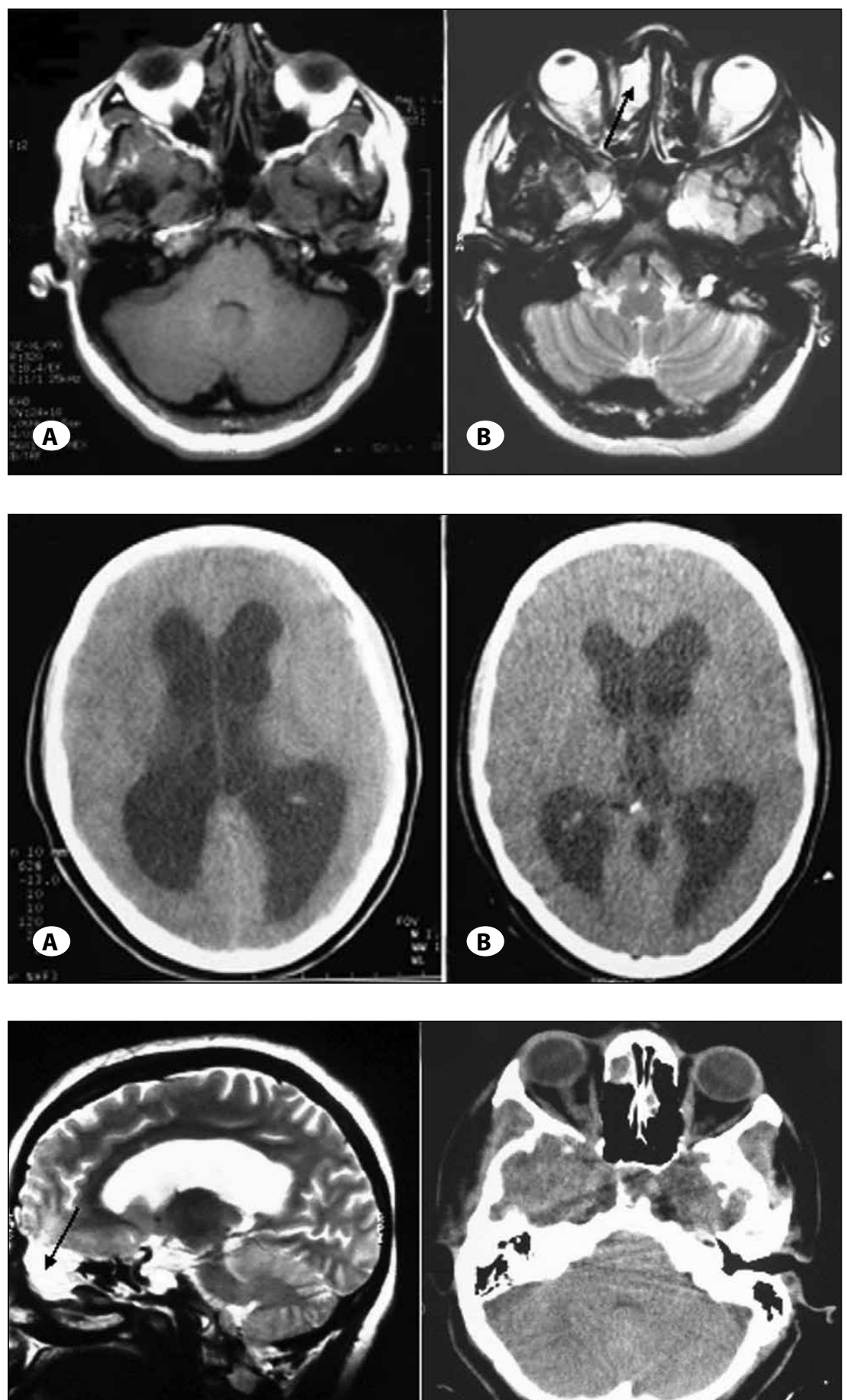

(A)

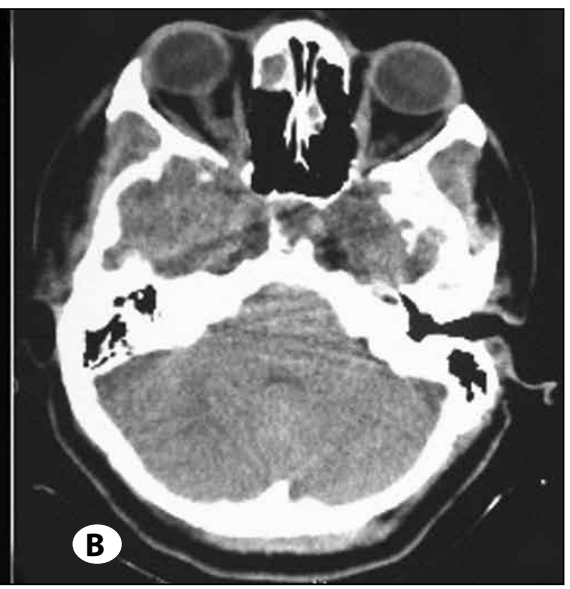

Figure 1: A) Pre-operative imaging showed aqueductal stenosis without anterior skull base defect, B) Axial MRI 9 months later shows dural sac and brain sag herniation.

Figure 2: A) Computed tomography at the first admission of the patient showed ventriculomegaly, B) CT scan at the second admission showed a good response to third ventriculostomy.

Figure 3: A) Dural sac and middle frontal gyrus herniation in the ethmoid sinus, 9 months after third ventriculostomy, B) Bone defect in fovea ethmoidalis on axial CT scan. 
As far as we know, there is no reported case of encephalocele after CSF diversion in the literature. The most important point is what would be the mechanism of such a phenomenon after reduction of high intracranial pressure.

Prolonged intracranial hypertension is an accepted cause of acquired skull base bone narrowing or defect (2). We propose that proximity of parasellar cisterns to fovea ethmoidalis and cribriform plate and high CSF flow in this region after CSF diversion were promoting factors of this phenomenon to develop.

We know that anterior subarachnoid space is a less important and less competent conduit for CSF transport. One can propose that high flow rate of CSF after diversion causes the inferior aspect of the frontal lobes displaced inferiorly.

The treatment of encephaloceles and CSF fistulae is usually surgical, although some patients benefit from nonsurgical therapy. For traumatic leaks and non-traumatic normal pressure leaks, the fistula must be located and repaired.

Despite numerous publications on the results of treatment of basal encephalocele, controversy remains whether the defect should be repaired intradurally or extradurally, and transcranially or endonasally (2).

An endoscopic approach has been successful in closing CSF fistula and cephaloceles in $86 \%$ to $100 \%$ of acquired cases (1). In this case, we removed all the remaining mucosa from the ethmoid roof after ethmoidectomy. Brain that has herniated into the nasal cavity is rarely functional and is considered a potential intracranial source of infection if not resected (2) so the herniated parenchyma was removed. A fat graft and fascia lata were harvested from the groin and also a septal graft was harvested from the nasal cavity and cleaned off all its mucosa as well. The fat was placed over the defect, and then fascia used for duraplasty and the septal graft placed on the intracranial side of the defect. We also placed a removable support (nasal tampon) for 2 days and lumbar drainage postoperatively to help seal the fistula.

Large bone defects in the floor of the anterior cranial fossa should be grafted because this helps support the dural repair and thereby lessens the risk of CSF leak (2). In our patient, the bone resorbed progressively in follow-up scanning. However, despite its absence there was no recurrence of encephalocele as the bone is usually replaced by fibrous tissue that prevents recurrent prolapse.

CSF diversion to parasellar cisterns is not a known iatrogenic cause of basal encephalocele and is not noted elsewhere as a complication of third ventriculostomy (1). Third ventriculostomy is usually performed for intracranial hypertension treatment and intracranial hypertension itself is a known but rare cause of lacunar skull defect. Such preexisting bone defects in new passage of CSF may cause this co-incidence to occur. We suggest endonasal endoscopic repair of such acquired non-traumatic basal encephaloceles as for other traumatic forms.

\section{REFERENCES}

1. Nyquist GG, Anand VK, Mehra S, KacKer A, Schwartz TH: Endoscopic endonasal repair of anterior skull base nontraumatic cerebrospinal fluid leaks, meningoceles, and encephaloceles. J Neurosurg 113:961-966, 2010

2. Schroeder HWS, Niendorf WR, Gaab MR: Complications of endoscopic third ventriculostomy. J Neusurg 96:1032-1040, 2002

3. Yilmaz C, Gulsen S, Altinors N, Caner H: Rhinorrhoea from a frontal encephalocele after reduction of high intracranial pressure. Acta Neurochir 150:1307 -1308, 2008 